\title{
The Role of the Community in Empowerment and Strengthening Citizenship Economy
}

\section{(Case Study in KWSLP Community at the City of Palu, Central Sulawesi)}

\author{
Siti Amanah ${ }^{1, *}$ Endang Danial ${ }^{2}$
}

\author{
${ }^{1,2}$ Universitas Pendidikan Indonesia \\ ${ }^{*}$ Corresponding author. Email: Sitiamanahupi.edu
}

\begin{abstract}
Economic growth is closely related to the welfare of society where it is said that a prosperous society is a society that has a better life. This means that all the needs of the community are met properly, without any shortcomings. Problem. The problems in social welfare that are developing today show that a country that has not fulfilled its basic needs properly because it has not been able to carry out its social functions, so it cannot live a decent and useful life. The community is an independent forum and social movement as well as a place for members to gather, making good relations between traders. The role of the community is able to have a positive impact on the economic empowerment of citizenship in the community, establish friendship, responsibility, independence, discipline, dare to take risks, be able to solve problems that occur, develop joint businesses, foster community participation in the social field, other benefits add assets to the community itself and are able to actively participate in realizing the good governance of Palu City government through the existence of the Community.
\end{abstract}

Keywords: Citizenship Education, Civic Economics, Community, Empowerment.

\section{INTRODUCTION}

The concept of civic education is never separated from two technical terms in foreign literature, namely civic education and citizenship education. Cogen [1] sserts that there is a difference between the understanding of civic education and citizenship education according to Cogen in general it refers to "formal education which is designed for and aims to educate the younger generation to become smart and aware citizens and aware of their rights and obligations. active in the community.

While citizenship education is a generic term that includes learning experiences both at school and outside of school (non-formal or informal such as in the family environment, in religious, community organizations, as well as media that help in the process of forming citizens as a whole.

David Kerr [5] said that citizenship education is widely formulate a process to prepare the younger generation to take on the role and responsibilities as a citizen, in particular the role of education including schools [2] . Citizenship education is expected to be able to prepare students to become citizens who have a strong and consistent commitment to defending the Unitary State of the Republic of Indonesia (NKRI). Not only educating the younger generation to become smart citizens and aware of their rights and obligations, but in the context of state life, citizenship education is an effort to build the readiness of world citizens. Able to compete in the global era.

Efforts to prepare the community accompanied by readiness and have the strength to be able to realize capabilities and welfare in society, make people independent and have care and have a position in the eyes of the law, a community empowerment is needed.

With the existence of economic growth, it is closely related to the welfare of the community, it can be said that a prosperous country is a society that has a good life. Like the opinion Of Danial [3] Many developed and prosperous countries are because their citizens are very concerned about welfare, they are aware of their rights and obligations as citizens of their country. The more advanced a society in its production business, the more prosperous the community in life. So that a developed country is a country that is prosperous in its life .

Efforts in the welfare of the community need what is called an empowerment in which there is a place to develop, develop their potential so that you can participate, participate, and share the same goal in fostering and providing insight so that they are able to 
develop their economy, make themselves and the community prosperous. able to compete with other countries.

The existence of the community makes a positive contribution in reducing the unemployment rate. Saepudin [4] a civic economic development is a suggestion to transfer and transfer knowledge in preserving the value of independence, namely creativity, innovation, self-confidence, visionary, the ability to make decisions, have leadership qualities and ideas, one of which is the existence of a community in empowerment, namely as an effort to combine different members, unite an interest and move forward together for the welfare of himself and others .

Without the development of a prosperous society, it will be difficult to create efforts to improve the welfare of the community. It must be based on economic growth. Therefore, it is necessary to develop and strengthen citizens in the values of nationalism and patritism which are the source of national awareness in the ideals of the nation in facing the challenges of globalization. states that national ideals are a struggle in an effort to realize national unity, one of which is in the economic realm .

\section{THEORETICAL REVIEW}

As for what is discussed is an overview of the moralspiritual approach, an overview of drugs, the theory of adolescent development, the concept of civic education , and the relationship between community empowerment and the civic economy.

\section{Civic Education}

Citizenship is a set of characters as a citizen. According to Winarno [15] citizenship indicates membership in a political community, which has implications for the ownership of the right to participate in politics. Citizenship Education according to the Regulation of the Minister of National Education Number 22 of 2006 concerning Content Standards for Primary and Secondary Education Units is a subject that focuses on the formation of citizens who understand and are able to carry out their rights and obligations to become Indonesian citizens who are intelligent, skilled, and have good character. mandated by Pancasila and the 1945 Constitution.

Furthermore, the opinion of Azis Wahab and Cholisin [13] explains that Civics is one of the learning media that Indonesianizes students as well as being aware, having intelligence and having full responsibility. Therefore, the Civics program contains general concepts in state administration, politics and state law, it also contains other general theories that are suitable for the taret. According to Winataputra [18], civic education is a field of study that has an object of study of virtue and civic culture, using the disciplines of education and political science as the main scientific framework as well as other relevant disciplines, which are coherently organized in forms of citizenship curricular programs, civic socio-cultural activities and scientific studies of citizenship. Meanwhile, according to Winata Putra \& Budimansyah [21] stated that Civics (civic education) is a subject of learning in carrying out the vision to foster the nation's character as a concrete effort towards "nation and character building".

\section{Empowerment Review}

Dwidjowijoto dan Weihatnolo [6] say that empowerment comes from the translation of a foreign language "empowerment" which can also mean "giving power, power", bias also means "power", so the word "daya" does not only mean "capable" but also has power . In line with this statement, Merriam Webster and the Oxford English Dictionary (in Guntur [7 ) explain that empowerment comes from a kaa empower which contains two meanings, namely: a) To give power or authority to. Giving power, transferring power or delegating authority to other parties. b) to give ability to or enable, which is an attempt to give confidence and ability to someone ]. Some literature says the concept of empowerment has been born since the industrial revolution or since the birth of modern Europe.

This is similar to what Suharto [8] stated about empowerment, power "empowerment" comes from the word "power" (power or empowerment) because the main idea of empowerment is related to the concept of power which is often also associated with our ability to see other people do what they want. we want and release their interest. In empowerment also includes the keys of power and weak groups of people.

According to Al-Fatih [19] empowerment is a series of efforts made to increase ability, development and independence so that it can bear better and better results in a better environment.

Empowerment is a way to improve development that involves the community in it. There is active participation from the community in every empowerment activity, in addition to the need for a forum or organization, the community that oversees every empowerment activity aims to make every activity or program implemented can run well. The most important thing in empowerment is how much benefit the community feels by holding empowerment activities. And in the end it boils down to changes in attitudes and independent behavior in the community.

In line with what was stated by Mardikanto and Soebianto [9] explained that empowerment is an implementation of a community-based development strategy. Any development or understanding given to it, always refers to a change, especially an improvement in the quality of human life, both physically, mentally, economically and socially. 
While the notion of empowerment according to Aileen Mitchell Stewart (dalam Nurmalina dan Syaifullah [22] yaitu:

Empowerment is quite simpe, a highly practical and production way to get the best from yourself and your staff. It goes beyond delegation to place real power where it can be used most effectivaly; close the costumer. This mean devolving not just tastk but decisian-making and full responsibility too.

The purpose of empowerment According to Payne in Adi, [23] are: making decisions and placing actions in doing something according to themselves, including efforts to reduce personal and social barriers by taking action. This is done through increasing ability and selfconfidence in using the power they have, including transferring power from the environment.

A concept of empowerment in development has a relationship with the concept of independence, participation and network groups and has a fair nature, Craig and Mayo (in Nugroho [24] participation in empowerment is the most important component in an effort to foster participation in society as the first issue of development. Currently, on the other hand, with community empowerment, there are also several problems that interfere with the implementation of community empowerment in a fabricated order.

According to Prasojo [25], a problem involves the absence of a clear concept of empowering the problem, the limits of successful communities in implementing empowerment, the community and the private sector, as well as the mechanisms for achieving them and so on.

\section{Economic Review civic}

The study of civic economics is still considered a new concept, although in the civic study itself concepts such as "civic community" have been developed from civic or citizenship, as well as environmental empowerment efforts (Community development). citizens and the state in relation to political life, but in the life of a person and group participating in aspiration in various lines of community institutions .

Civic economics is defined as the development of an advanced economic science such as political economy or economic policy. According to Danial, E [3] explained that the political economy has been sufficiently developed by experts who study it. So that it is very difficult to separate politics and economics in practice in the life of the state. In the study of political science and economics, it is easy to distinguish because they have quite strict scientific principles, but in practical studies, citizens and government are very difficult to distinguish.

"The Greek state is indeed democratic in the participation of all citizens, not only in the election of officials but in the daily routine of administration and justice; who pushed their belief in equality to the former filled many posts by drawing losers, assuming that one person as a whole was as good as another"

\section{Community Overview}

In essence, Citizenship Education can be understood as the "heart" or all things related to the life of citizens including the implementation of obligations and fulfillment of their rights. The study can be continued on the second word of the term civic community, namely community content (community). C ommunity comes from the Latin communitas which means "similarity" or in English community which means society, unity or substantive set, community is understood as all forms of social movement groups consisting of several individuals on the basis of common residence, interest in a thing or thought. to achieve certain goals. Social movements carried out by the community through collective action create a new traditional order, but a sense of membership in the existing collectivism creates a sense of belonging and between community members (Wikipedia,; Blackshaw, T, [10] .

According to Wrihatnolo and Dwidjowijoto [11] community is defined as "Community is a subgroup having many of the characteristics of society, but on a smaller scale, and with less extension and coordinated common interest $s$. Implicit in the concept of "community" is a territorial area, a considerable degree of interpersonal acquaintance and contact, and some special basic of coherence that separates it from neighboring groups. The community has more limited self-sufficiency than society, but within those limits has closer association and deeper sympathy.

In line with that, the development of the role of civic and non-citizen organizations or communities in diversity and the goals of achieving justice and social welfare in accordance with Pancasila. The context of interaction and participation carried out by citizens in the form of associations that are oriented towards national matters has actually been regulated in the 1945 Constitution of the Republic of Indonesia and related articles of the 1945 Constitution, including article $28 \mathrm{C}$ paragraph (2) which reads "everyone has the right to promote himself in fighting for his rights collectively to build his community, nation and state" as well as Article 28 E paragraph (3) which reads "everyone has the right to freedom of association, assembly and expression " If ideologically the two articles are truly optimized their realization as a right, citizens who are very active in participating in development will be obtained, the two articles are also a reinforcement that theoretically the concept of civic community developed so far is in accordance with the legal basis of the Indonesian nation (Winitiputra, US, [12]).

According to Abdullah (in Payoka, V [20] ,) in its development the term community experienced rapid development starting in the 14th century which was 
originally used to denote a group of people who are in a low situation, due to the similarity of the goals of the vision and mission of the group. So that the 16th century the community has changed its meaning to "kesanab" with its identity and characteristics into a group of people who have an interest in "community of interest" so that in the 19th century the difference between community (community) and (society) in society distinguishes the environment not only in breadth. unit but also at the formal level of the unit. Community is also referred to as a relatively less formal system compared to society

Lee, M.R \& Thomas, SA [17] Community perspective is defined as that there are similarities and classic ideas and social ecology in organizations. Dmana will make a contribution to the spread of scientific discourse. Related to that, the community perspective is not limited by the environment and determined by social control, but has a wider context.

Lowson, L \& Kearms, A [14].In a community, it aims to refer to people who are in a certain area that has a broad scope, seen in several forms of community in an organization

a. The first component is "Capabilities" in a policy on capacity building which includes components, knowledge, understanding

b. The second component "Deciding) Somerville (1998) explains that in empowerment there is a question of what helps in making effective the community's ability to consider their opportunities to do something.

c. The third component, in community empowerment, is also the ability of an institution to act directly, thus leading to actions from others based on the decision.

\section{RESEARCH METHOD}

This research uses a qualitative approach with a case study method. The case study or research field called the research to investigate the focus of an event stage, activity, program, groups of people. A case is limited by time and activities, then the researcher explores the information as a whole by applying a series of procedures to collect data over the specified time.

Participation of the research that will be carried out by researchers in qualitative research is people who are in direct contact with the community of KWSLP. The participation consisted of the chairman of KWSLP, KWSLP management, representatives of KWSLP members from various regions. Then the data collection techniques used by the researchers consisted of interviews, observation, and documentation. The series of data analysis techniques are carried out through data reduction, data presentation, and data verification.

\section{RESULTS AND DISCUSSION}

According to BN as the Head of KWLSP , the plan carried out in an effort to empower the community is to identify problems in Palu City, Central Salawesi. Especially for the Warung Sari Laut traders, RF also explained that an important problem to find alternative solutions was the relation to the Warung Sari Laut traders. Therefore, BN and SD along with sea sari traders took the initiative to gather community leaders, including community leaders representing each sub-district in Palu City. , community leaders, religious leaders and attended by 8 people from Warung Sari Laut traders, 2 representatives from each region. Based on the results of the association, an idea was generated to form a nongovernmental group that focuses on the profession of seafood traders, this group was later named the Harmony of Warung Sari Laut, which according to BN was formed on November 11, 2014.

KWLSP is the only forum for professional organizations and social, economic movements that are independent and have a populist economy which is a place to gather and fight in the morning for all sea sari stall traders in the city of Palu. Harmony Sari Laut is also an organization that has a clear vision and mission based on the findings of three main approaches, namely, an individual approach, KWSLP management such as providing counseling to the community about the benefits of joint entrepreneurship. This means that this approach is an approach that starts individually or personally, this personal approach is carried out (in Mardikanto and Soebianto [9] mentions the term in this micro approach, namely the approach taken to the beneficiaries (clients) through counseling guidance activities (stress management \& crisis). intervention) in it has expectations to be achieved so that clients do it by carrying out their life tasks.This model is often referred to as a task-centered approach.

Next is the group approach, activities related to this group approach are socialization activities to community members related to working together to build entrepreneurship. Provide run debugging activities. With community and community leaders who work as seafood traders as well as various outside communities to commit to creating an organization that aims as a means of communication between communities who work as sellers of seafood. This means that this approach is an activity carried out directly to certain community groups or communities. This approach is also termed by Parsons (in Mardikanto and Soebianto, [9] this approach begins with groups who are benefited (clients) through empowerment by using various media tools, education, training, intervention in each group dynamic. And strategies are usually carried out as well. to increase awareness, regarding knowledge, skills and various attitudes so that problem solving abilities can be faced properly. Finally, the participatory approach is carried 
out by the harmony of Sari Laut Palu by providing free menu lists for each member of KWSLP, providing an entrepreneurial program, namely the KWSLP barn. and the KWSLP cooperative, which is a program to increase the income of each member who invests in. When the market price always rises while KWSLP members always need basic commodities every day for entrepreneurship, then the introduction of KWSLP barns will make it easier for members to get basic materials $\mathrm{k}$ at an affordable price the KWSLP barn is a barn that contains basic needs for entrepreneurs, including (cooking oil, rice, gallon water, and other spices). KWSLP itself produces ingredients from the island of Java so the price is cheaper than the market price. This makes it easier for members to get their needs very easily, besides that the results from the KWSLP barn itself usually become income for KWSLP members themselves. From this explanation, the participatory approach is an approach given to someone to actively participate in empowerment. This is in line with a principle of empowerment described by Mardikanto and Soebianto which states that the participatory approach directs the community as the focal point (a) this empowerment always has a goal in carrying out empowerment (b) implementing methods and techniques in empowerment based on community choice (c) success in empowerment is measured by facilitators who come from outside

Empowerment activities in a community are expected to be achieved well, therefore every empowerment must be based on a certain performance which is often interpreted as taking steps or taking action in order to achieve a goal desired by the beneficiary.

Based on the findings, it was found that the strategy used by KWSLP in an effort to empower and strengthen the economy of its members is that the planning stage of the planning process is an important thing that should not be missed in empowerment efforts. White (in Suharto[8]) revealed that "if we fail to plan we plan to fail" which means if we fail in planning, then we plan to fail. This principle is also the main guideline for the harmony of the sea juice of the hammer KWSLP because at this stage it is considered capable of knowing the steps or actions that should be taken in order to achieve the desired goals.

Suharto [8] stated that essentially planning is a conscious, organized and continuous effort to have a good alternative from the number of alternatives that exist to achieve certain goals. In this case, the harmony of the sea sari Palu KWSLP carried out planning which consisted of the following program activities. The plan for production activities, initially various problems arose with the sellers of the hammer seafood stall, namely taxation that always went up, the security aspect was not guaranteed because these seafood sellers operated at night so that there were a lot of criminals, and there were many sellers of sea juice as they pleased. lower menu prices to attract customers. Finally, with problems that arose, the management and the TIM sought a way out by taking care of a permit letter and asking for security protection from the Palu City Police. Furthermore, conducting follow-up program activities such as a socialization program to sellers of hammer sea juice regarding matters related to the decline in menu prices, this socialization is carried out to find problems regarding what caused the decline while other members are still at the agreed price. Explaining to members that cheap prices will not always guarantee that the food will sell, because in terms of good food, even though the price is expensive, people will still buy it because of the taste.

Second, the implementation stage. That is the implementation of what was previously planned. Harmony of the sea juice of the hammer KWSLP in an effort to achieve the planned empowerment goals carried out various implementation efforts such as, (1) building cooperatives, (2) making barns (3) making their own chicken slaughter (4) procuring the needs needed by KWSLP members, one of which is giving banners and menu lists to each member, as well as carrying out social, religious and economic activities related to the community in establishing friendship and brotherhood among members. The implementation of activities here is a program not only in terms of looking for profit alone, but the program run by the Harmony of Sari Laut Palu KWSLP also carries out social programs, namely helping when members are hit by a disaster, KWSLP shares help when there is a disaster, for example floods, earthquakes, and carrying out religious activities, namely recitations. build a prayer room. Based on the implementation stages above, Mardikanto and Soebianto [9] state that empowerment strategies are the efforts made by every individual, organization, group or company that wins the competition, in order to achieve the expected or set goals.

\section{CONCLUSION}

Based on the results of the research conducted, the author can draw conclusions regarding "the role of the community in empowering and strengthening the citizenship economy carried out in the KWSLP in the city of Palu, Central Sulawesi.

KWSLP is a form of community as a forum for people who work as sellers of sea sari food stalls in the city of Palu. And is the only community. The approaches and strategies used by KWSLP in empowering and strengthening the economy of its members are through 3 approaches, namely the micro (individual) approach, the mazzo (group) approach and the participatory approach. implementation stage. the approach and strategy used for the realization of a strong KWSLP, making the seafood trader profession to take part in participating in advancing KWSLP and realizing the members of the KWSLP who are prosperous and just, helping to build the 
city of Palu to be even better, from material and nonmaterial aspects so that good governance is realized

\section{ACKNOWLEDGMENTS}

We thank the Universitas Pendidikan Indonesia and the 3rd Annual Civic Education Conference "Civic Education in Pandemic Covid-19: Challenges and Responses" for support.

\section{REFERENCES}

[1] Cogen, J,J, "Developing the Civil Society: The Role of civic education." Bandung: CICED, 1999.

[2] Keer, D, "Citizenship education." international camparason. London: National Foundational For Education Reserch-NFEER, 1999.

[3] Danial Endang, A, "Economi civic (membina waega Negara; Bepartisipasi dan berpartisipasi dalam system ekonomi nasional untuk meningkatkan kesejahteraan masyarakat", Bandung: Laboratorium PKn UPI, 2007.

[4] Saefudin, Epin "penguatan nilai kesukaralaan dalam membagun ekonomi kewarganegaraan bagi masyarakat demokratis melalui situs kewarganegaraan (studi kasus pada komunitas bandung creative city forum)." Tesis sekolah pascasarjana universitas pendidikan Indonesia, 2014.

[5] Isjwara, F "Pengantar ilmu politik," Bandug; Bina Cipta Angkasa, 1982.

[6] Dwidjowijoto dan Wrihatnolo, "Manajemen Pemberdayaan: Sebuah pengantar dan panduan untuk pemberdayaan masyarakat." Jakarta; PT Elex Media Komputindo, 2007.

[7] Guntur, E, "Pemberdayaan Ekonomi Rakyat." Jakarta: Sagung Seto, 2009.

[8] Suharto, E, "Membangun Masyarakat Memberdayakan Rakyat: Kajian Strategis Pembangunan Kesejahteraan Sosial \& Pekerjaan Sosial. Bandung: Reflika Aditama, 2014.

[9] Mardikanto dan Soebiato, "Pemberdayaan Masyarakat Dalam Perspektif Kebijakan Publik." Bandung: Alfabeta, (2015).

[10] Wikipedia, Komunitas, Diakses Pada Tanggal 28 mei 2020 dari Halaman web Obline, 2015, https;//id.m.wikipedia.org/wiki/komunitas

[11] Wrihatnolo dan Dwidjowijoto, "Manajemen Pemberdayaan," Jakarta: Elex Media Komputindo, 2007.

[12] Winataputra U.S, "Pendidikan Kewarganegaraan dalam persfektif Pendidikan untuk mencerdaskan kehidupan bangsa (Gagasan, Instrumentasi, dan Praktis.” Bandung; Wdya Aksara Press, 2012
[13] Wahab, A \& Sapriya "Teori dan Landasan Pendidikan Kewarganegaraan” Bandung; Alfabate, 2011.

[14] Lawson, L \& Kearns, A. "Rethinking the purpose of community empowerment in neighbourhood regeneration" The need for policy clarity. LocalEconomy, 29(1-2),65-81. 2014 https://doi.org/10.1177/0269094213519307

[15] Winarno "Kewarganegaraan Indonesia dari sosiologi menuju uridis", Banudng; Alfabeta 2009.

[16] Samsuri "Pendidikan Karakter Warga Negara", Yogyakarta: Diandra Pustaka Indonesia. 2011

[17] Lee, M. R., \& Thomas, S. A. "Civic Community, Population Change, and Violent Crime in Rural Communities". Journal of Research in Crime and Delinquency, $\quad 47(1), \quad 118-147.2010$. https://doi.org/10.1177/0022427809348907

[18] Wunataputra U.S "Pendidikan Kewarganegaraan dalam persfektif Pendidikan untuk mencerdaskan kehidupan bangsa (Gagasan, Instrumentasi, dna Praktis" Bandung; Wdya Aksara Press 2012

[19] Al fatih, Andy "Implementasi kebijakan dan pemberdayaan masyarakat" Bandung; UNPAD press, 2010

[20] Payoka, V "Peran komunitas fotografi pekanbaru (kfp) dalam transformasi ilmu fotograf" jurnal Fisip 1(2), oktober 2014

[21] Budimansyah, D. dan Udin Winataputra "Pendidikan Kewarganegaraan dalam Perspektif Internasional" Bandung; Widya Aksara Press 2012

[22] Nurmalina, "Komala, dan Syaifullah materi pokok pendidikan kewarganegaraan" Bandung :Universitas Pendidikan Indonesia, 2008

[23] Adi, Isbandi Rukminto. "Intervensi komunitas pengembangan masyarakat sebagai upaya pemberdaayaan masyarakat" Jakarta; Rajawali perss. 2008

[24] Nugroho, Trilaksono. "Paradigma, Model, Pendekatan Pembangunan, dan Pemberdayaan Masyarakat di Era Otonomi Daerah". Malang, FIA. Universitas Brawijaya 2007

[25] Prasojo, Eko. "People and Society Empowerment: Perspektif Membangun Partisipasi Publik". Jurnal Ilmiah Administrasi Publik vol.IV no.2. MaretAgustus:10-24, 2004 